\title{
Inappropriate Sexual Behaviours as Perceived by Students in the Institute of Education, Delta State University, Abraka: Implication for Counselling
}

\author{
Grace Omoni ${ }^{1} \&$ Anna Onoyase ${ }^{1}$ \\ ${ }^{1}$ Department of Guidance and Counselling, Delta State University,P.M.B 1, Abraka, Delta State - Nigeria \\ Correspondence: Anna Onoyase, Department of Guidance and Counselling, Delta State University, P. M. B 1, \\ Abraka, Delta State - Nigeria. E-mail: tinaonoyase@gmail.com
}

Received: December 29, 2018

Accepted: April 1, 2019

Online Published: April 2, 2019

doi:10.5539/ijps.v11n2p54

URL: https://doi.org/10.5539/ijps.v11n2p54

\begin{abstract}
The purpose of this study was to examine the perception of students in the Institute of Education on the incidence of inappropriate sexual behaviours among students at Delta State University, Abraka. A total of 334 students in Business Education and Library Science Education completed a questionnaire with items on pre-marital sex, pornographic materials, sexual abuse and indecent dressing. The instrument for the study was a 22 - item "Youth Assessment of Inappropriate Sexual Behaviour Interest Inventory" (YASPII). The instrument had acceptable content and face validity. It had a Cronbach alpha reliability index of .75. Four research hypotheses were tested. Findings of the study revealed that pre-marital sex, pornographic films and indecent dressing were perceived by students as common forms of inappropriate sexual behaviour. There was however disparity in their perception of sexual abuse as a form of inappropriate behaviour. It was recommended that sexuality education be scaled up in Nigerian higher education institutions.Counselors and other stakeholders should sensitize students on the consequences of viewing pornographic materials, engaging in pre-marital sex and wearing indecent clothing.
\end{abstract}

Keywords: inappropriate sexual behaviour, sexuality education, pre-marital sex, indecent dressing, pornographic materials

\section{Introduction}

The concept of sexual behaviour refers to the organization and expression of an individual's eroticism and/ or emotional attachment with reference to the sex and gender of the partner involved in sexual activity. Wikipedia (2012) view sexual behaviour as the manner in which human beings experience and express their sexuality and this involves a number of activities such as sexual intercourse, non - penetrative sex, oral sex, hugging, kissing and holding of hands amongst others.

Furthermore, Mohammed (2012) identified five types of sexual behaviours found among secondary school students and these include kissing, breast and genital fondling, embracing, holding of arms and sexual intercourse. Obiunu (2014) equally observed that the incidence of inappropriate sexual behaviours is on the increase among secondary school adolescent students in Delta State and that these negative behaviour manifest in different ways which usually involve a strong desire to experiment on sexual activities. Much of this sexual behaviour appear to be in aberration to values cherished by the Nigerian society. Due to urbanization, technology and global changes, youths' engage in inappropriate or deviant sexual behaviour such as pre-marital sex, heterosexual relationships, lesbianism, exhibitionism to name but a few. Youths are found to engage in indiscriminate sexual activities culminating in teenage pregnancy, loss of virginity, acquisition of sexually transmitted infections including HIV/ AIDS, high level of promiscuity, school drop-out, stealing, bullying and other forms of deviant behavour prevalent among this demographic group. The Nigerian society frowns at these.

Agardh, Tumwine and Ostergren (2011) observed that pre-marital sex was unacceptable to religious individuals in Uganda and that becoming pregnant stigmatizes not only the individual but the church as well. To buttress the above observation, Nnonye (2012) opined that previous studies have shown that traditional norms seem to limit talks about sexuality and when taken, it is prohibitory, misleading, confusing and contradictory. Could it be that the lackadaisical attitude of parents and guardians would have warranted the present inappropriate behaviour of 
university students towards their sexuality? The problem of this study is to investigate inappropriate sexual behaviours of students in the Institute of Education, Delta State University, Abraka and explore ways counselling could be utilized to minimize such. Newspapers today repeatedly give reports of unusual sexual behaviour such as rape, lesbianism, incest, homosexuality and teenage pregnancies. Other examples according to Aji and Aji, Ifeadike, Emelumadu, Ubajaka, Nwabueze and Azuike (2013), Obiunu (2014), Agbede, Kio and Ajetunmobi (2016) include unsafe or unprotected sex, multiple sex partners, masturbation, sexual harassment and sexual bullying. These negative behaviours no doubt are at variance with most African cultures. In the view of Ahonsi (2013), the prevalence of sexual behaviour among adolescents at various levels of the educational system in Nigeria cannot be over-emphasized; he further stated that deviant sexual behaviour has assumed such an alarming proportion that it has become of great concern to members of the Nigerian society. Still on sexual behaviour of students, Ekundayo and Oyeniyi (2008) and Adebule (2012) enumerated negative sexual behaviour of students to include sex abuse, sex offences, sexual misconduct, immorality and promiscuity.

\subsection{Sexual Behaviour}

Human beings express their sexuality in different ways. Different sexual acts and behaviours, other than penetrative penis - vaginal intercourses are used by different people to express their sexual urges. Sexual behaviour varies from one culture to another and from one person to another. Each individual is entitled to his or her sexual rights. Nevertheless, there are acceptable and unacceptable sexual behaviours within a given society. There are variations which are either acceptable or unacceptable in a given society. Thus, what is considered 'abnormal' or 'inappropriate' is a deviation from what the society values. Such deviant sexual behaviour are prevalent among youths. These have been found to be practiced by students of Delta State University. These include indecent assault (touching of breasts or buttocks), cuddling, rape, pre-marital sex, watching of pornographic film, displaying of nude pictures, engaging in incest, multi-sex partners, oral sex, web-dating, engaging in sex with older persons (Sugar Daddy/ Mummy), indecent dress code, peeping, masturbation, exhibitionism, voyeurism, and use of objects to satisfy sexual urges. According to Odunukwe (2012) in Nwoye (2002), sexual behaviour includes sexual acts such as masturbation, kissing, sexual intercourse, dressing, walking in certain ways and others. What is really worrisome to the researchers is that these students who are being groomed to attain high moral values seemed to have lost moral restraint and now constitute great problem to the society.

\subsubsection{Some of these sexual bebaviour are hereby explained:}

Sexual Abuse: This is also referred to as molestation. It is the forcing of undesired sexual behaviour by one person upon another. It can also be described as any act that produces feelings of discomfort and humiliation, that violates another's right as it relates to sexuality. It is also referred to, as any sort of non-consensual act. It can happen to men and women. The offender is referred to as a sexual abuser. Some acts of sexual abuse include rape, sexual harassment, touching of any part of the body, incest and forced early marriage.

Rape: Rape can be described as an act of violence in which sexual activity is forced on a person as means of humiliating and degrading the individual. Yumi (2014) posited that the most assumed reasons for rape are irresistible impulse, mental illness or disease, alcohol or drugs and victims precipitation Mfrekemfon, and Nwakwaola (2015) defined rape as an oral, anal or vaginal penetration that involves threat or force against an unwilling person, younger than the age of consent.

Incest: This is an act of sexual intercourse between close blood relatives such as father and daughter, brother and sister, between cousins or between an uncle and the niece. The first encounter is often accidental but thereafter, it becomes calculated and pre-meditated.

Masturbation: Masturbation can be defined as a process through which an individual obtains sexual satisfaction by massaging his sexual organs without indulging in sexual intercourse. Sharafi (2000) in Shekarey, Rostami, Mazadia and Mohammadi (2011) outlined 19 factors as the causes of masturbating and these include curiosity, unfamiliarity with sexual issues, seduction, inferiority complex, imitation, unsuitable clothes, unsuitable classroom seats, lack of affection amongst others. According to the Encyclopedia of Social Deviance (2014), masturbation is the first kind of sexual activity that teenagers engage in and that it enables them (teenagers) to explore their own sexuality and become acquainted with their body.

Pornography/Pornographic Materials: Pornography has no well-defined meaning. However, internetsafety 101.org outlines that it can be thought of, as all sexually explicit materials intended primarily to arouse the reader, viewer or listener. These include indecent materials harmful to minors and obscenity. Pornographic materials include messages or pictures on telephone, radio or films and television broadcast that are patently offensive, depictions or description of sexual organs. They also include close-up of graphic sex acts, 
lewd exhibition of the genitals and deviant activities such as group sex and incest. With the advent of Information Communication Technology (ICT), most adolescents now have access to the internet where they obtain sex- related information which could lure them into negative sexual activities. In the views of Okpare and Ebenuwa-Okoh (2013), viewing of bad television programmes, reading immoral magazines and also watching pornographic films have prompted youths to participate in immoral acts.

Pre-Marital Sex: This refers to sexual activities practiced by people who are unmarried. In other words, it is the act of engaging in sexual acts before marriage. It is culturally biased and takes place in a number of situations such as casual sex or between a couple living together in a longtime relationship without marriage. This is frowned upon in African societies. There are likely sexual behaviours that could make youths pre-dispose to premarital sex. According to Ajiboye, Aina, Oyebanji and Awoniyi (2014), such sexual behaviour are sexual fantasy, masturbation, pornographic viewing, kissing and touching. In another study by Ekpenyong and Ekpenyong (2016), parental influence, economic reasons, peer pressure, academic pursuit and search of pleasure were identified as reasons for the practice of pre-marital sex among students of Niger Delta University, Bayelsa State, Nigeria. Furthermore, these authors have observed that Nigerian University undergraduates indulge in pre-marital sex and justify their actions by saying that "sex is fun" and that "everybody is doing it". Put in another way, these youths do not perceive pre-marital sex as inappropriate. The consequences of these inappropriate sexual behaviours outlined above to the individual and the society cannot be over-emphasized; they include stigmatization, loss of integrity, teenage pregnancy, dropping out of school, cultism and health hazards.

Sexuality Education: Sexuality education can be defined as a process of acquiring knowledge and skills and forming attitudes, beliefs and values with regard to human sexuality. (Ministry of Education, Singapore, 2016). This ministry outlined the objectives of sexuality education in schools to include the followings; assists students to understand the physiological, social and emotional changes they experience as they mature, develop healthy and rewarding relationship with their peers and make wise, informed and useful decisions on sexuality matters. In a world where young people are exposed to several influences which impinge upon their sexual attitudes and behaviour on a daily basis, there is great need to provide them (youths) with adequate and accurate information about their sexuality so as to make appropriate decisions.

Indecent Dressing: This connotes dressing in an undignified way by exposing one's vital parts such as the breasts, armpits, pubic hair, tummy, laps, buttocks and contours. It is also called provocative or inappropriate dressing because it arouses the opposite sex sexually. Those who wear such dresses expose their bodies and provide opportunity for lusts. Examples of such dresses include monostraps, micro or miniskirts, spaghetti backless tube (internet safety 101.org).

The manner of dressing no doubt is an integral aspect of the culture of any society (most especially African Societies). From observation, during the socialization process, children are taught by their parents and significant others, to imbibe the tenets of their tradition, such as an appropriate dressing code. Indecent dressing was highly condemned and those dressed in such ways were seen to be "promiscuous".

Egbule (2013) opined that modernization has led to the eroding of African values and that decent dress patterns have now been replaced with transparent and provocative dresses which many of the youths do not consider as inappropriate. Additionally, Eregare (2018) decried the rate at which students presently engage in open display of deviant behaviours such as smoking and unacceptable dressing styles which are at variance with the norms of the Nigerian society.

\section{Research Hypotheses}

The following research hypotheses were formulated to guide the study:

Hypothesis I: There is no significant difference between female and male students of the Institute of Education in their perception of pre-marital sex as an inappropriate sexual behaviour.

Hypothesis 2: There is no significant difference between Business Education and Library Science students of the Institute of Education in their perception of pornographic materials as inappropriate sexual behaviour.

Hypothesis 3: There is no significant difference between Year 1 and Year 2 students of the Institute of Education in their perception of sexual abuse as an inappropriate sexual behaviour.

Hypothesis 4: There is no significant difference between Business Education and Library Science Education students at the Institute of Education in their perception of indecent dressing as an inappropriate sexual behaviour. 


\section{Purpose of the Study}

The purpose of this paper therefore was to ascertain the extent and prevalence of inappropriate sexual behaviour among the students at the Institute of Education, Delta State University with a view to counselling them on appropriate sexual behaviour.

\section{Significance of the Study}

The study would help counselors perform their roles in promoting students' sexuality education within the university environment and helping them to develop positive sexual behaviour acceptable to the larger society.

\section{Design}

It is a cross- sectional, non - experimental design using a questionnaire.

\section{Population}

The population consisted of the 3,200 students in the Institute of Education (Diploma Programme), at Delta State University, Abraka.

\section{Sample and Sampling Technique}

A purposive sampling technique targeting students from Business Education and Library Science Education Units was used. $20 \%$ of the students in the eleven programmes in the Institute of Education, Delta State University, Abraka were targeted. A total of 334 respondents completed the questionnaire.

\section{Instrumentation}

A questionnaire titled "Youth Assessment of Inappropriate Sexual Behaviour Interest Inventory" was used to collect information from the respondents. It was divided into two sections; (A \& B). Section A sought to elicit information on the respondents' biodata based on their sex, type of programme, level and religious background. Section B consisted of 22 items divided into four - (a) Pre- marital sex (b) pornographic materials (c) sexual abuse and (d) indecent dressing. The 4-point modified Likert-type scale aggregate of SA - Strongly Agree (4), A - Agree (3); D - Disagree (2) and SD - Strongly Disagree (1) was used to score the responses.

\section{Validity and Reliability of the Instrument}

For content and face validity, the instrument was given to four lecturers in Guidance and Counselling Department and the Institute of Education. The instrument was scrutinized and corrections were made. It had a reliability result index of .75 using the test retest method at 0.05 level of significance.

\section{Administration of Instrument}

The researchers personally administered the questionnaire to the students during the lecture periods with the assistance of the group coordinators. These were retrieved on the spot and recorded a $100 \%$ response rate.

\section{Data Analysis}

An independent samples T- Test was run using SPSS 16 software. The test statistics sought to determine whether there were significant differences in the perception of sexual behaviour across the groups.

\section{Presentation of Result}

\section{Hypothesis I}

There is no significant difference between female and male students of the Institute of Education in their perception of pre-marital sex as an inappropriate sexual behaviour.

Table 1. T-Test Analysis of female and male students of the Institute of Education in their perception of pre-marital sex as an inappropriate sexual behavior

\begin{tabular}{lllllllll}
\hline Variable & N & Mean & SD & Df & t-cal & t- crit & $\begin{array}{l}\text { Level of } \\
\text { sign }\end{array}$ & Of decision \\
\hline Female & 240 & 11.90 & 1.88 & 332 & 0.79 & 1.96 & 0.05 & $\begin{array}{l}\text { Not significant } \\
\text { (Accepted) }\end{array}$ \\
Male & 94 & 11.71 & 1.95 & & & & &
\end{tabular}

Table 1 showed that the t-calculated value of 0.79 was less than the t-critical value of 1.96 . Therefore, the null hypothesis was accepted. This implies that there was no significant difference between female and male students of the Institute of Education in their perception of pre-marital sex as an inappropriate sexual behaviour. 


\section{Hypothesis 2}

There is no significant difference between Business Education and Library Science students at the Institute of Education in their perception of pornographic material as inappropriate sexual behaviour.

Table 2. T-test Analysis of Business Education and Library Science Students of the Institute of Education in their perception of pornographic materials as inappropriate sexual behaviour

\begin{tabular}{llccccccc}
\hline Variable & N & Mean & SD & Df & t-cal & t- crit & $\begin{array}{l}\text { Level of } \\
\text { sign }\end{array}$ & Of decision \\
\hline $\begin{array}{l}\text { Business } \\
\begin{array}{l}\text { Education } \\
\text { Students }\end{array}\end{array}$ & 165 & 14.59 & 2.58 & & & & & \\
$\begin{array}{l}\text { Students } \\
\text { Library Science } \\
\text { Students }\end{array}$ & 169 & 14.15 & 2.61 & & & & & $\begin{array}{l}\text { Not significant } \\
\text { (Accepted) }\end{array}$ \\
\hline
\end{tabular}

In table 2, the t-calculated value of 1.57 was less than the t-critical value of 1.96 . Hence, the null hypothesis was accepted. This shows that there was no significant difference between Business Education and Library Science students of the Institute of Education in their perception of pornographic materials as an inappropriate sexual behaviour.

\section{Hypothesis 3}

There is no significant difference between Year 1 and Year 2 students of the Institute of Education in their perception of sexual abuse as an inappropriate sexual behavior.

Table 3. T-test Analysis of Year 1 and Year 2 students of the Institute of Education in their perception of Sexual Abuse as an inappropriate sexual behavior

\begin{tabular}{lllllllll}
\hline Variable & N & Mean & SD & Df & t-cal & t- crit & $\begin{array}{l}\text { Level of } \\
\text { sign }\end{array}$ & Of decision \\
\hline Year 1 & 240 & 27.59 & 3.98 & 332 & 2.34 & 1.96 & 0.05 & $\begin{array}{l}\text { Significant } \\
\text { (Rejected) }\end{array}$ \\
Year 2 & 94 & 26.44 & 4.28 & & & & & \\
\hline
\end{tabular}

The result in table 3 showed that the t-calculated value of 2.34 was greater than t-critical value of 1.96. Hence, the null hypothesis was rejected. This indicates that there was a significant difference between Year 1 and Year 2 students of the Institute of Education in their perception of sexual abuse as an inappropriate sexual behaviour.

\section{Hypothesis 4}

There is no significant difference between Business Education and Library Science Education students of the Institute of Education in their perception of indecent dressing as inappropriate sexual behaviour.

Table 4. T-test Analysis of Business Education and Library Science Education students in their perception of indecent dressing as an inappropriate sexual behaviour

\begin{tabular}{|c|c|c|c|c|c|c|c|c|c|}
\hline Variable & & $\mathbf{N}$ & Mean & SD & Df & t-cal & t- crit & $\begin{array}{l}\text { Level of } \\
\text { sign }\end{array}$ & Of decision \\
\hline $\begin{array}{l}\text { Business } \\
\text { Students }\end{array}$ & Education & 165 & 11.90 & 2.39 & \multirow{2}{*}{332} & \multirow{2}{*}{1.13} & \multirow{2}{*}{1.96} & \multirow{2}{*}{0.05} & \multirow{2}{*}{$\begin{array}{l}\text { Not significant } \\
\text { (Accepted) }\end{array}$} \\
\hline $\begin{array}{l}\text { Library } \\
\text { Students }\end{array}$ & Science & 169 & 11.58 & 2.83 & & & & & \\
\hline $\begin{array}{l}\text { The resul } \\
\text { Therefore } \\
\text { Business } \\
\text { dressing a }\end{array}$ & $\begin{array}{l}\text { table } 4 \mathrm{r} \\
\text { e null hyl } \\
\text { cation anc } \\
\text { appropria }\end{array}$ & $\therefore$ & Scien & Idel & $C^{c}$ & it & Educ & $\begin{array}{l}\text { n the } t-c \\
\text { significan } \\
\text { in their } p\end{array}$ & $\begin{array}{l}\text { itical value of } 1.96 \text {. } \\
\text { difference between } \\
\text { rception of indecent }\end{array}$ \\
\hline
\end{tabular}

\section{Discussion of Findings}

The first finding of this study has revealed that there is no significant difference between female and male students at the Institute of Education in their perception of pre-marital sex as inappropriate sexual behaviour. This implies that, irrespective of their sex, students regard pre-marital sex as inappropriate sexual behavior. The findings is in line with Agardh, Tumwine and Ostergen (2011) who observed that pre-marital sex was unacceptable to Christians in Uganda and that becoming pregnant stigmatizes not only the individual but the church as well. Again, this finding resonates with the views of Okonkwo and Eze (2000) who opined that in 
traditional Nigerian society, girls avoided pre-marital sex for fear of the punishment they would receive if they defiled themselves. Also, this finding corroborates the views of Ajiboye, Aina, Oyebanji, Awoniyi (2014) who reiterated that pre-marital sex is morally unacceptable in nearly all human society that see marriage as the legitimate requirement for sexual permissiveness and especially among youths who are seen as being vulnerable to health related problems. The finding is at variance with the assertion of Ekpenyong and Ekpenyong (2016) that Nigerian University undergraduates indulge in premarital sex and justify their actions by saying that "sex is fun".

The finding also revealed that there is no significant difference between Business Education and Library Science students of the Institute of Education in their perception of pornographic materials as an inappropriate sexual behaviour. This finding supports the opinion of Eregare and Ebenuwa-Okoh (2013) that viewing of bad television programmes and watching of pornographic films have prompted youths to participate in immoral acts.The finding agrees with that of Omoni (2013) who found that adolescents' access to information technology influences their sexual behaviour. The study revealed that males and females shared the same view that youths access to the internet, television, books, magazines and videos, films and printed media do have influence on their sexual orientation. This also agrees with Buadi (2000) who asserted that youths copy a lot of bad patterns of behaviour from the media.

This study also found that there is a significant difference between Year 1 and Year 2 students of the Institute of Education in their perception of sexual abuse as an inappropriate sexual behaviour. This finding contradicts Baker (2013), who found out from a survey to establish and quantify the extent to which Princeton University students experience assault. According to the survey, more than $28 \%$ of female undergraduate students reported that they were touched in a sexual manner or had their clothes removed without consent. $12 \%$ said they were forced to receive or perform oral sex and a further $14 \%$ said that they were victims of attempted forced oral sex. Another $6.2 \%$ of female undergraduate respondents said they experienced attempted rape while about $2 \%$ said that male undergraduates inserted fingers or objects into their vagina without their consent. This result may be so because adolescents now regard sexual abuse as a way of life.

Lastly, table 4 of this research indicated that there was no significant difference among the respondents in their view of indecent dressing as an inappropriate sexual behaviour. This finding agrees with the assertion of Ehusani (2005) that young people, notably those in tertiary institutions and especially many of the female members are often more guilty of running a-foul of public morality in dressing, making some tertiary institutions moral degeneracy hotspots. This is equally supported by Okwudishu and Uzoaku (2005) who asserted that indecent dressing was a sign of moral decadence. Furthermore, she posited that the citadels of learning which turns out graduates described as certified fit both in character and learning is gradually being turned into areas where students dressed indecently while walking in and out of the lecture halls and other parts of the university. She therefore, advocated that moral education at the lower levels of the educational system should be intensified to enable the higher education institutions to inherit a crop of students that are morally conscious and recognized the need to uphold the dignity exemplified in the local cultural context. The finding also corroborates the view of Egbule (2013) that modernization has led to the eroding of African values and that decent dress patterns have now been replaced with transparent and provocative dresses. Again, the last finding supports Eregare (2018) who decried the rate at which students presently engage in open display of deviant behaviour such as smoking and unacceptable dressing style which are at variance with the norms of the Nigerian society.

\section{Conclusion}

This paper examined the perception of students on the incidence of inappropriate sexual behaviour in the Institute of Education, at Delta State University, Abraka. The responses of the students showed that the practice of inappropriate sexual behaviour was rampant. Pre-marital sex, pornographic materials, sexual abuse and indecent dressing were in vogue among the students. There was therefore, need for counsellors, educators and stakeholders to assist the youths in re-defining values on their sexuality as dictated by the local cultural norms and values.

\section{Counselling Implications}

Some of the counselling implications are:

1. Counsellors are needed in higher institutions to provide adolescents information on the dangers of pre-marital sex.

2. Counsellors should encourage adolescents to refrain from watching pornographic materials and obscene films as these have adverse effects on their sexuality.

3. Counsellors should train students to understand actions which constitute sexual abuse and the skills needed to resist and avoid such actions/ attitude. 
4. There is the need for counselors to intimate the youths on the consequences of indecent dressing, imitating or copying fashion that exposes their bodies.

They are also to be given tips on how to make right choices in terms of dressing.

\section{Recommendations}

As guided by the findings, the following recommendations were made:

1. Sexuality education should be encouraged in the university environment. Students need to be made aware of the importance of reproductive health, dangers of teenage pregnancy, consequences of pre-marital sex, pornography, sex abuse and indecent dressing. This will help the youths acquire information and skills to better manage their sexual reproductive health.

2. Seminars should be organized by counselors to inculcate appropriate values in students especially in the area of girls preserving their virginity and boys respecting girls who insist on waiting till marriage before engaging in sexual activity. They would learn to respect and value themselves and others.

3. Grassroots campaigns should be organized in the area of appropriate dress code among youths in the tertiary institutions. It is equally recommended that there should be a dress code for the students in the different programmes in universities and this should be enforced by the authority. The students' body is expected to have their input on this issue (dress code) so that they can be carried along.

4. Laws should be enforced by the government and appropriate authorities to ban and prohibit obscene books, films and pornographic materials from infiltrating into the Nigerian society. Government should devise a way of preventing youths from sourcing materials relating to inappropriate sexual behaviour from websites.

5. Counselling centres should be established in all higher institutions of learning. Counsellors should take it as a point of duty to assist students to exhibit appropriate behaviour through individual, group counselling and group guidance activities.

6. Counsellors should train peer educators who will also train their peers on making right relationships with the opposite sex in order to avoid pre-marital sex and sexual abuse.

7. There should be sensitization to create awareness of the need for dress codes.

\section{References}

Adebule S O. (2012). Moral discipline and academic performance of Secondary School Students in Ekiti State of Nigeria. Paper presented at the International conference on Education, Ireland, United Kingdom.

Agardh A Tumwin G. \& Ostergren P. (2011). The impact of Socio-Demographic and Religious Factory upon Sexual Behaviour among Ugandan University Students.

Agbede O C, Kio J O \& Ajetunmobi A A. (2016). Analysis of the Influence of the Internet on Sexuality Education and Sexual BehaviourAmong Adolescent in Nigeria Universities: The Case of University of Lagos. Journal of Biology, Agriculture and Health, 6(16), 74 - 83.

Ahonsi B A. (2013). Targeting Youth for HIV Prevention and Care in Nigeria: What Role for Governments. African Journal of Reproductive Health, 17(4).

Aji J, Aji M O, Ifeadike C O, Emelumadu O F, Ubajaka C, Nwabueze U E \& Azuike E C. (2013). Adolescent Sexual Behaviour and Practices in Nigeria. Twelve - Year Review. AFRIMEDIC Journal, 4(1), 10 - 16.

Ajiboye S K, Aina J S, Oyebanji T O \& Awoniyi S A. (2014). Possible causes of Premarital Sex Among Youths as Perceived by Lecturers of University of Ilorin, Nigeria. European Journal of Educational Sciences, 1(4).

Akinade E E. (2006). Sexuality Education and Couple Guidance. Ibadan: Oluaki Publishers.

Baker J M. (2013). Princeton Buries Rape Survey Report, only to have it leaded later. The Daily Princetonian, March 4.

Buadi J M. (2013). Television violence and vicarious Behaviour in Jike V. T. (ed). "Ethnic Militia and Youth Rebelliousness in Contemporary Nigerian: A Book of Readings" 131 - 137.

Egbule O E. (2013). Counselling for Appropriate Dressing on Campuses of Institutions of Higher Learning in Nigeria”. A paper presented at the 2013 Annual conference of the Delta State Chapter of the Counselling Association of Nigeria. (CASSON).

Ehusani G. (2009). Dress code and the challenges of social dislocation in Education Today. A Quarterly Journal of the Federal Ministry of Education, 12(1), 3-7.

Ekpenyong N S \& Ekpenyong A S. (2016). Perceived Factors Influencing Premarital Sexual practice Among University Students in Niger Delta University, Bayelsa State, Nigeria. Canadian Social Science, 12(11), 80. 
Ekundayo H T \& Oyeniyi P. (2008). Issues in Examination Malpractices in Nigerian Educational System. Journal of Educational Foundation and Management, 6(1), 158 - 166.

Encyclopedia of Social Deviance. (2014). Masturbation. United States of America: Sage Publications. 3 of 8.

Eregare E J. (2018). Peer Group Influence and single parenting as Factors of Deviant BehaviourAmong Secondary School Students in Delta North Senatorial District. Unpublished M.Ed Dissertation, Delta State University, Abraka.

Kinanee L B. (2009). Sexuality education and Marital Guidance in Oniyama, E. E. Omoni, G. E. and Ijeh, U.S. (ed)., Essentials of Guidance and Counselling. Benin-City: Ayo-Mats Prints, 186 - 197.

Mfrekemfon P I \&Nwakwaola C L (2015). Rape and the Girl Child . Journal of Dental and Medical Sciences, 14(1), $52-56$.

Ministry of Education Singapore. (2016). Sexually Education. [Online] Available: https://www.moe.gov.sg/education/programmes/social-and-emotional-learning/sexuality-education.

Mohammed D A. (2012). Influence of Family Life Education on Sexual behaviour of Secondary School Students in Nigeria State, Unpublished M.Ed Dissertation, University of Nigeria, Nsukka.

Nnonye T. (2012). Attitude of Parents towards Sexuality Development of their children Implications for Counselling. The Lagos Counsellor. An Official Publication of Lagos State Chapter, Counselling Association of Nigeria, 5(1), $13-21$.

Obiunu J J. (2014). The influence of sexuality Education on Inappropriate Sexual Behaviours among Secondary School Student's Advances in Research, 2(12), $869-878$.

Oday J E. (2004). The role of the family is sex and sexuality education. The Journal of family development, 1(2), $76-85$

Odunukwe G E. (2002). The Influence of Social Environment of the Development of the Nigerian Child. In R. U. N. Okonkwo and R O. Okoye (Eds). The Learning Environment of the Nigerian Child. A Publication of the Nigerian Society of Education Psychologists.

Okonkwo RUN \& Eze I. (2000). Attitude of Nigerian Adolescents to Pre-marital Sexual Behaviour: Implications for Sex Education. Journal of Counselling, 1(1), 21 - 26.

Okpare B \& Ebenuwa - Okoh E. (2013). Curbing Indiscipline among Students in Nigerian Secondary Schools for National. Development: Implications for Counselling. A paper presented at the 2013 Annual Conference of the Delta State Chapter of the Counselling Association of Nigeria (CASSON).

Okwudishu A \& Uzoaku. (2005). A Dress Code for Students Addressing the Moral Decadence in Institutions" in Education Today. A Quarterly Journal of the Federal Ministry of Education, 12(1), 3- 7.

Omoni G E. (2013). Adolescents Access to Information Technology and the Influence on Sexual Quality Counselling for Positive Transformation in DELSU. Journal of Educational Research and Development, $12(1), 116-124$.

Sharafi M R. (2000). World of Teenagers. Tehran, Iran: Culture Institute of Education.

Shekarey A, Rostami M S, Mazdai K H \& Mohammadi A. (2011). Masturbation: Prevention and Treatment. [Online] Available: www.sciencedirect.com.

What is Pornography? Retrieved from www.internet.safety101.org.2013.

Wikipedia. (2012). Developmental Psychology. [Online] Available: https://wikipedia.org/wiki/peer group.

Yumi E S (2014). Rape: Theories. [Online] Available: https://www.researchgate.net/publication/277330647.

\section{Copyrights}

Copyright for this article is retained by the author(s), with first publication rights granted to the journal.

This is an open-access article distributed under the terms and conditions of the Creative Commons Attribution license (http://creativecommons.org/licenses/by/4.0/). 